\title{
PENGEMBANGAN LKPD SMA BERDASARKAN KERAGAMAN TANAMAN OBAT MASYARAKAT DESA PONDOK PANJANG MUKOMUKO
}

\author{
Ariefa P. Yani ${ }^{{ }^{*}}$, Erin Mei Juliyanti ${ }^{1}$, Sri Irawati ${ }^{1}$ \\ ${ }^{1}$ Program Studi Pendidikan Biologi, Fakultas Keguruan dan Ilmu Pendidikan, Universitas Bengkulu \\ Email: Erinmeijuliyanti831@gmail.com
}

\begin{abstract}
Abstrak
Penelitian ini bertujuan untuk mengidentifikasi jenis-jenis tanaman obat yang terdapat di Desa Pondok Panjang Kabupaten Mukomuko, untuk kemudian diaplikasikan dalam lembar kerja peserta didik (LKPD) materi keanekaragaman hayati. Jenis penelitian ini yaitu penelitian dan pengembangan dengan mengacu pada model Sugiyono. Lokasi pengambilan sampel dilakukan di Desa Pondok Panjang Kabupaten Mukomuko. Uji respon LKPD dilakukan di Sekolah Menengah Atas (SMA) Negeri 5Mukomuko. Berdasarkan hasil penelitian ditemukan 45 spesies (28 famili) tanaman obat yang terdapat di Desa Pondok Panjang Kabupaten Mukomuko. Famili yang paling banyak dimanfaatkan adalah Zingiberaceae yaitu 5 jenis tanaman. Hasil validasi terhadap LKPD yang disusun memperoleh kriteria sangat valid, dengan nilai $89 \%$ oleh para validator dan uji respon oleh 10 peserta didik kelas $X$ SMAN 5Mukomuko mendapat respon sangat baik dengan nilai $90 \%$. Berdasarkan hasil tersebut dapat dinyatakan bahwa desain LKPD yang disusun layak digunakan sebagai bahan ajar tingkat SMA kelas $\mathrm{X}$ pada materi keanekaragaman hayati.
\end{abstract}

Kata kunci: Lembar Kerja Peserta Didik, Tanaman Obat, Desa Pondok Panjang

\begin{abstract}
This research aimed to identify the types of medicinal plants found in Pondok Panjang Village, Mukomuko Regency, and then to be applied in the worksheets of students (LKPD) on biodiversity material. The sampling location was carried out in Pondok Panjang Village, Mukomuko Regency. Whereas the LKPD response test was conducted at the Mukomuko 5 State Senior High School. Based on the research result, 45 species ( 28 families) of medicinal plants found in Pondok Panjang Village, Mukomuko Regency. The most widely used family was Zingiberaceae with 5 types of plants. The validation results of the compiled LKPD obtained very valid criteria, with a value of $89 \%$ by the validators and test responses by 10 students of class X SMAN 5 Mukomuko received very good responses with a value of $90 \%$. Based on these results it can be stated that the LKPD design prepared is suitable for use as teaching materials for grade $\mathrm{X}$ high school students on biodiversity material.
\end{abstract}

Keywords: Worksheet Student, Medicinal Plants, Pondok Panjang Village

\section{PENDAHULUAN}

Indonesia merupakan salah satu negara yang memiliki keanekaragaman spesies tumbuhan terbesar. Sebagian besar jenis tumbuhan di Indonesia dapat dimanfaatkan sebagai bahan obat. Tanaman obat adalah tumbuhan yang dapat dipergunakan sebagai obat, baik yang disengaja ditanam maupun tumbuh secara liar yang dapat ditemukan diberbagai belahan dunia, salah satunya di
Negara Indonesia (Wasito, 2011). Obat yang berasal dari berbagai jenis tumbuhan atau bahan alam ini dikenal dengan sebutan obat tradisional. Penggunaan obat yang berasal dari tanaman lebih diminati oleh masyarakat dengan alasan lebih murah dan minim efek samping dibanding dengan menggunakan obatobat kimia. Tanaman obat-obatan memiliki manfaat bagi manusia, hewan ataupun untuk keseimbangan alam (Sada dan Tanjung, 2010).Mengingat khasiatnya 
terbukti mampu menyembuhkan penyakit dan penggunaannya lebih efektif, efisien, aman dan ekonomis. Maka sudah saatnya disosialisasikan kepada masyarakat secara terus menerus, sehingga tertanam budaya menggemari tanaman obat sebagai pilihan yang sejajar dengan pengobatan medis (Leonardo dan Fathul, 2013).

Berdasarkan survei dan wawancara yang telah dilakukan diketahui bahwa masyarakat di desa ini masih menggunakan jasa dukun (Battra) untuk mengobati penyakit yaitu dengan memanfaatkan tumbuh-tumbuhan yang ada di sekitar dan di hutan. Kepercayaan tentang pengobatan ini terjadi secara turun temurun. Sebagian besar masyarakat di desa Pondok Panjang tidak memiliki pengetahuan dalam memanfaatkan tumbuhan sebagai obat.

Upaya yang dapat dilakukan yaitu memberikan pengetahuan tentang pemanfaatan tumbuhan obat melalui pembelajaran. Kegiatan pembelajaran yang dapat memfasilitasi pengetahuan tumbuhan obat yaitu mata pelajaran Biologi. Pembelajaran tersebut memerlukan bahan ajar yang spesifik tentang tumbuhan obat sekitar.

Bahan ajar yang dapat digunakan dalam proses pembelajaran ada berbagai bentuk, salah satu diantaranya yaitu bahan cetak berupa lembar kerja peserta didik (Majid, 2009). Lembar kerja peserta didik (LKPD) yaitu bahan ajar yang sudah dikemas sedemikian rupa, sehingga peserta didik diharapkan dapat mempelajari materi ajar tersebut secara mandiri (Prastowo, 2011).

Berdasarkan hasil observasi di SMAN 5 Mukomuko, guru belum menggunakan LKPD yang didesain dengan memanfaatkan lingkungan sekitar sebagai sumber informasi. Pembuatan bahan ajar dan guru hanya menggunakan LKPD yang berasal dari penerbit sebagai bahan ajar. LKPD tersebut kurang sesuai dengan kebutuhan peserta didik, karena berisi materi dan soal yang kurang kontekstual karena bukan berasal dari lingkungan peserta didik. Hal tersebut menunjukkan bahwa perlu dikembangkan LKPD berdasarkan potensi lingkungan sekitar yang lebih menarik dan inovatif. LKPD yang dikembangkan mengacu kepada Kompetensi Inti (KI) dan Kompetensi Dasar (KD) kurikulum 2013.

Tujuan penelitian ini adalah untuk 1) mengidentifikasi jenis-jenis tanaman obat yang terdapat di Desa Pondok Panjang dan organ-organ tumbuhan yang dimanfaatkan serta cara penggunaannya, 2) mengembangkan desain LKPD materi kenekaragaman hayati.

\section{METODE}

Jenis penelitian ini adalah penelitian dan pengembangan (Research and Development). Metode penelitian yang digunakan dalam penelitian ini, yaitu metode Borg and Gall yang dimodifikasi oleh Sugiyono (2008).

Penelitian ini dilakukan pada bulan Juni - Agustus 2019. Subjek penelitian ini adalah peserta didik kelas $X$ SMAN 5 Mukomuko. Objek penelitian adalah LKPD sebagai bahan ajar materi keanekaragaman hayati sub keanekaragaman jenis. Pengambilan sampel jenis-jenis tanaman obat dilakukan di Desa Pondok Panjang Kabupaten Mukomuko. Validasi LKPD dilakukan oleh ahli materi, ahli media dan praktisi pendidikan.

Teknik pengumpulan data yang digunakan adalah observasi, wawancara, dan angket. Prosedur penelitian mengacu pada Sugiyono (2008), dengan beberapa modifikasi dikarenakan penelitian ini terbatas pada uji keterbacaan atau uji respon setelah revisi desain. Adapun langkah-langkah pada penelitian ini adalah; potensi dan masalah, pengumpulan data, desain produk, validasi 
desain, revisi desain, dan uji keterbacaan atau uji respon. Data penelitian keragaman tanaman obat di Desa Pondok Panjang Kabupaten Mukomuko dianalisis secara deskriptif. Data validasi dan uji keterbacaan atau uji respon LKPD dipersentasekan untuk masing-masing responden menggunakan rumus:

Presentase $=\frac{\text { jumlah skor lembar validasi }}{\text { Skor maksimal }} \times 100 \%$

(Riduwan, 2015)

Persentase skor kemudian dirata-ratakan dengan rumus:

$$
\begin{aligned}
\mathrm{X}= & \frac{\mathrm{A}}{n} \\
& \text { (Riduwan, 2015) }
\end{aligned}
$$

Skor persentase uji validasi dan respon diinterpretasikan dalam data kualitatif dengan mengacu pada Tabel 1.
Tabel 1. Kriteria Hasil Validasi

\begin{tabular}{cc}
\hline Persentase & Kriteria \\
\hline $81-100$ & Sangat Valid \\
$61-80$ & Valid \\
$41-60$ & Cukup Valid \\
$21-40$ & Kurang Valid \\
$0-20$ & Sangat Tidak Valid \\
\hline
\end{tabular}

\section{HASIL DAN PEMBAHASAN}

Penelitian yang telah dilakukan di desa Pondok Panjang Kabupaten Mukomuko diperoleh 45 jenis tanaman obat yang terdiri dari 28 famili. Famili tanaman obat yang banyak digunakan sebagai obat di Desa Pondok Panjang adalah Acanthaceae, Araceae, Arecaceae, Crassulaceae, Malvaceae, Myrtaceae, Piperaceae, Rutaceae, dan Zingiberaceae. Famili dengan keragaman terbanyak adalah Zingiberace yaitu sebanyak 5 jenis. Jenis tanaman obat yang dimanfaatkan Desa Pondok Panjang Kabupaten Mukomuko dapat dilihat pada Tabel 2.

Tabel 2. Jenis-Jenis Tanaman Obat yang dimanfaatkan oleh Masyarakat Desa Pondok Panjang

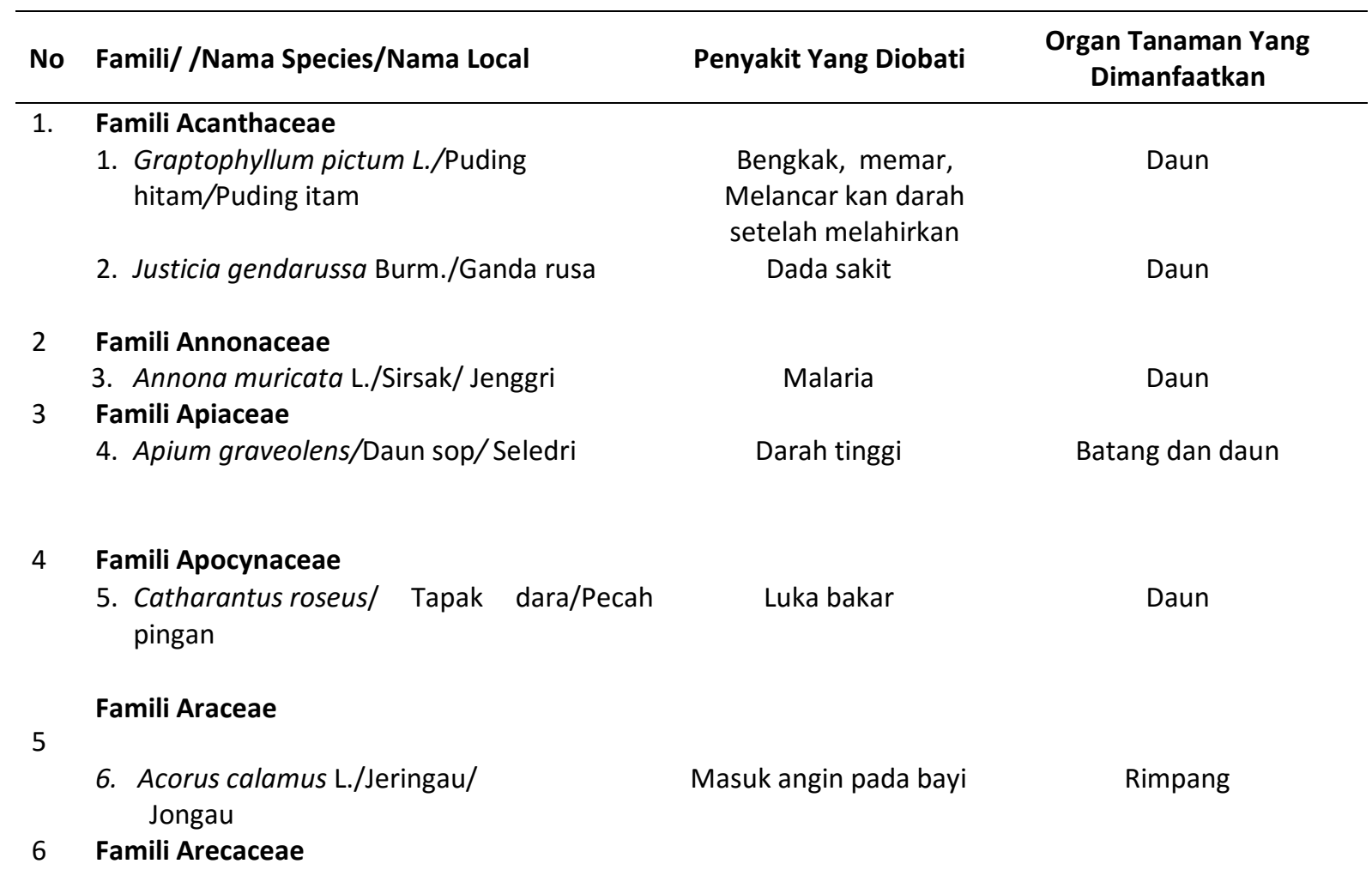




\begin{tabular}{|c|c|c|c|}
\hline No & Famili/ /Nama Species/Nama Local & Penyakit Yang Diobati & $\begin{array}{l}\text { Organ Tanaman Yang } \\
\text { Dimanfaatkan }\end{array}$ \\
\hline & 7. Areca catechu/Pinang/ Pinang & Diare & Biji \\
\hline & 8. Cocos nucifera/Kelapa hijau/Kelapo ijau & Diare & Buah \\
\hline & & Luka yang terkena & Buah \\
\hline & $\begin{array}{l}\text { 9. Elaeis guineensis/Kelapa sawit/kelapo } \\
\text { sawi }\end{array}$ & $\begin{array}{l}\text { tusukan duri ataupun } \\
\text { Besi }\end{array}$ & \\
\hline \multirow[t]{2}{*}{7} & Famili Asteraceae & & \\
\hline & $\begin{array}{l}\text { 10.Blumea balsamifera /Daun sembung } \\
\text { /Daun capo }\end{array}$ & Demam, pilek & Daun \\
\hline \multirow[t]{2}{*}{8} & Famili Balsaminaceae & & \\
\hline & 11. Impatiens balsamina /Pacar air/Inai aie & $\begin{array}{l}\text { Kuku sakit/kuku } \\
\text { canggu }\end{array}$ & Daun \\
\hline \multirow[t]{2}{*}{9.} & FamiliBombaceae & & \\
\hline & 12.Durio zibethinus/Durian & Bisul & Daun \\
\hline \multirow[t]{2}{*}{10} & FamiliCaricaceae & & \\
\hline & 13. Caricapapaya/Pepaya/sapelo & Malaria & Daun \\
\hline \multirow[t]{2}{*}{11} & FamiliClusiaceae & & \\
\hline & 14.GarciniamangostanaL./Manggis/Mangih & Rematik & Buah \\
\hline \multirow[t]{2}{*}{12} & FamiliCrassulaceae & & \\
\hline & $\begin{array}{l}\text { 15. Brasilensis pinnata } / \text { Cocor } \\
\text { bebek/Sedingin }\end{array}$ & $\begin{array}{l}\text { Batuk } \\
\text { berdahak }\end{array}$ & Daun \\
\hline \multirow[t]{3}{*}{13} & FamiliCucurbitaceae & & \\
\hline & 16.Cucumis sativus/Mentimun/Lepang & Jerawat & Buah \\
\hline & 17.Momordica charantiaL./Pare/Poyo & Sakit Kepala & Daun \\
\hline \multirow[t]{4}{*}{14} & Famili Euphorbiaceae & & \\
\hline & 18. Jatropha curcas/Jarak pagar/Jerak & $\begin{array}{l}\text { Sakit perut (Masuk } \\
\text { angin) }\end{array}$ & Daun \\
\hline & 19.Manihot utilisima/Singkong/Ubi kayu & Obat gatal pada bayi & Umbi \\
\hline & 20.SauraphusandrogyusMerr./Katu & Penambah ASI & Daun \\
\hline \multirow[t]{4}{*}{15} & Famili Fabaceae & & \\
\hline & $\begin{array}{l}\text { 21.Leucaenaleucocephala /Petai cina/Petai } \\
\text { cina }\end{array}$ & Cacingan & Biji \\
\hline & 22.Mimosapudica/Putrimalu/Sekejut & Sesak nafas & Akar dan daun \\
\hline & 23.Vigna cylindrical/Kacang panjang & Sakit pinggang & Daun \\
\hline \multirow[t]{4}{*}{16} & Famili Lamiaceae & & \\
\hline & $\begin{array}{l}\text { 24.Coleus blumei benth/Jawer } \\
\text { kotok/Pigueng }\end{array}$ & Cacingan & Daun \\
\hline & 25.Ocimum citriodorum/Kemangi/ Kemangi & Masukangin & Daun \\
\hline & $\begin{array}{l}\text { 26.Orthosiphon aristatus/Kumis } \\
\text { kucing/Sungut kucing }\end{array}$ & $\begin{array}{l}\text { Sakit pinggang, obat } \\
\text { kencing sakit, batu } \\
\text { ginjal, rematik }\end{array}$ & Daun, bunga \\
\hline 17 & Famili Liliaceae & & \\
\hline & 27.Aloe vera/Lidah buaya/lidah boyo & Rambut rontok & Daun \\
\hline 18 & Famili Magnoliaceae & & \\
\hline
\end{tabular}




\begin{tabular}{|c|c|c|c|}
\hline No & Famili//Nama Species/Nama Local & Penyakit Yang Diobati & $\begin{array}{l}\text { Organ Tanaman Yang } \\
\text { Dimanfaatkan }\end{array}$ \\
\hline & $\begin{array}{l}\text { 28. Michelia champaca L./Cempaka/ } \\
\text { Cempago }\end{array}$ & Kesapo & Bunga \\
\hline \multirow{2}{*}{19} & Famili Malvaceae & & \\
\hline & $\begin{array}{l}\text { 29.Hibicus rosa- sinensis /Kembang } \\
\text { sepatu/bungo gayo }\end{array}$ & $\begin{array}{l}\text { Panas dalam/ bibir } \\
\text { pecah- pecah }\end{array}$ & Daun \\
\hline \multirow{3}{*}{20} & Famili Myrtaceae & & \\
\hline & & & \\
\hline & 30. Psidium guajava L. /Jambu biji/Jalimu & $\begin{array}{l}\text { Diare, demam } \\
\text { berdarah (DBD) }\end{array}$ & Daun, buah \\
\hline \multirow[t]{2}{*}{21} & $\begin{array}{l}\text { 31. Syzygium polyanthum/Daun salam } \\
\text { Famili Oleaceae }\end{array}$ & Asam urat & Daun \\
\hline & $\begin{array}{l}\text { 32. Jasminum sambac/Bunga melati/Bungo } \\
\text { pecan }\end{array}$ & Panas dalam & Bunga \\
\hline \multirow[t]{2}{*}{22} & Famili Oxalidaceae & & \\
\hline & 33.Averhoa bilimbi/ Belimbing wuluh & Darah tinggi & Daun \\
\hline \multirow[t]{2}{*}{23} & Famili Piperaceae & & \\
\hline & 34.Piper betle L. /Sirih/sigeh & Obat sakit mata & Daun \\
\hline \multirow[t]{3}{*}{24} & FamiliPoaceae & & \\
\hline & 35.Cymbopogon citratus/Serai/Seghai & Obat sakit gigi & Batang \\
\hline & $\begin{array}{l}\text { 36.Imperatacylindriaca /Alang- alang/Lalang } \\
\text { Famili Rosaceae }\end{array}$ & Ambien & Akar \\
\hline . & 37. Rosa hybrid/Bungamawar/Bungumawar & Obat sakit mata & Bunga \\
\hline 26 & Famili Rutaceae & & \\
\hline . & $\begin{array}{l}\text { 38.Citrus aurantiifolia/Jeruk nipis/Limau } \\
\text { kapeh }\end{array}$ & Batuk & Buah \\
\hline \multirow[t]{3}{*}{27} & Famili Solanaceae & & \\
\hline & 39.Phyalis zangulata L./Ceplukan/Celetup & Malaria & Akar dan daun \\
\hline & 40.Solanum torvum/Rimbang/ Rangoi & Obat sakit mata & Buah \\
\hline 28 & Famili Zingiberaceae & & \\
\hline . & 41.Alpiniagalanga L./Lengkuas/ Lekueh & Panu & Rimpang \\
\hline & 42.Curcuma domestica/ Kunyit/kunyit & $\begin{array}{c}\text { Untukmelancarkan } \\
\text { darah setelah } \\
\text { melahirkan }\end{array}$ & Rimpang \\
\hline & 43.Kaempferia galanga L./Kencur/Cekua & Terkilir & Rimpang \\
\hline & 44. Zingiber officinale/Jahe/Sapedeh & Obat sakit perut & Rimpang \\
\hline & 45. Zingiber pururem/ Bangle /Kunyit molai & Obat sakit Perut & Rimpang \\
\hline
\end{tabular}

Adapun hasil validasi LKPD dari ahli bahan ajar, ahli media, dan guru biologi dapat dilihat pada Tabel 3.

Tabel 3. Hasil Validasi LKPD

\begin{tabular}{clcl}
\hline No & Validator & Persentase & Kriteria \\
\hline 1 & Validator I (Ahli Bahan Ajar) & $90 \%$ & Sangat Valid \\
2 & Validator II (Ahli Materi) & $82 \%$ & Sangat Valid \\
3 & Validator III (Guru Biologi) & $95 \%$ & Sangat Valid \\
\hline & Rata-rata persentase & $89 \%$ & Sangat Valid \\
\hline
\end{tabular}


Sedangkan hasil uji keterbacaan dapat dilihat Pada Tabel 4.

Tabel 4. Hasil Uji Keterbacaan

\begin{tabular}{|c|c|c|c|c|c|}
\hline \multirow[t]{3}{*}{ No } & \multirow[t]{3}{*}{ Kriteria } & \multicolumn{4}{|c|}{ Tanggapan } \\
\hline & & \multicolumn{2}{|c|}{ Ya } & \multicolumn{2}{|c|}{ Tidak } \\
\hline & & Jumlah & $\%$ & Jumlah & $\%$ \\
\hline 1 & Susunan kalimat pada LKPD mudah dipahami dan jelas & 10 & 100 & - & - \\
\hline 2 & Petunjuk dan prosedur pada LKPD sudah jelas & 9 & 90 & 1 & 1 \\
\hline 3 & $\begin{array}{l}\text { Materi pada LKPD menarik dan menambah wawasan tentang } \\
\text { tumbuhan obat }\end{array}$ & 9 & 90 & 1 & 1 \\
\hline 4 & $\begin{array}{l}\text { Gambar di dalam LKPD memiliki kejelasan dan kelengkapan } \\
\text { keterangan }\end{array}$ & 9 & 90 & 1 & 1 \\
\hline 5 & $\begin{array}{l}\text { Penyajian materi pada LKPD mendorong untuk lebih banyak } \\
\text { membaca }\end{array}$ & 8 & 80 & 2 & 2 \\
\hline 6 & Penyajian materi pada LKPD medorong rasa keingintahuan & 8 & 80 & 2 & 2 \\
\hline 7 & $\begin{array}{l}\text { Bahasa yang digunakan pada LKPD komunikatif dan mudah } \\
\text { dipahami }\end{array}$ & 9 & 90 & 1 & 1 \\
\hline 8 & Tampilan desain cover atau sampul depan LKPD menarik & 10 & 100 & - & - \\
\hline 9 & Tata letak gambar dan tulisan jelas dan baik & 9 & 90 & 1 & 1 \\
\hline 10 & Kualitas cetakan gambar dan tulisan jelas dan baik & 9 & 90 & 1 & 1 \\
\hline & Jumlah rata-rata persentase & \multicolumn{2}{|c|}{$90 \%$} & \multicolumn{2}{|c|}{$10 \%$} \\
\hline
\end{tabular}

Jenis tanaman yang ditemukan di

\section{Desa Pondok Panjang Kabupaten} Mukomuko berjumlah 45 jenis tanaman obat yang digolongkan ke dalam 28 famili. Penyakit yang bisa diobati berjumlah 33 penyakit. Hasil ini berbeda dengan hasil penelitian yang dilakukan oleh Kasrina, dkk (2015) pada etnis Mukomuko yang menemukan 78 jenis dari 37 famili. Penyakit yang diobati ada 51 penyakit. Perbedaan jumlah keanekaragaman jenis tanaman yang dimanfaatkan sebagai obat serta perbedaan jumlah penyakit yang di obati ini diduga karena adanya perbedaan daerah, kondisi alam dan juga perbedaan pengetahuan tentang pengobatan yang diwariskan sejak zaman dahulu secara turun temurun. Hal ini sesuai dengan pernyataan Jumiarni (2017), bahwa setiap daerah atau suku bangsa memiliki ciri yang khas dalam hal pengobatan. Ciri khas tersebut dilatarbelakangi oleh adanya perbedaan kondisi alam, ketersedian tumbuhan yang berkhasiat obat, perbedaan falsafah budaya, adat dan istiadat.

Keragaman jenis tanaman obat yang paling banyak ditemukan adalah dari famili Zingiberaceae yaitu sebanyak 5 jenis. Hal ini sama dengan penelitian yang telah dilakukan oleh Sari (2016) bahwa famili yang paling banyak ditemukan juga dari famili Zingiberaceae yaitu berjumlah 8 jenis tanaman. Famili Zingiberaceae ini banyak ditemukan karena selain mudah dikembangbiakan serta dimanfaatkan sebagai obat, juga bisa digunakan sebagai bumbu masak sehari-hari. Hal itu sesuai dengan penelitian Lestaridewi, dkk (2017) Famili Zingiberaceae mudah dikembangbiakan serta berkhasiat secara turun temurun dalam mengobati berbagai penyakit. Jika ditinjau dari kandungannya menurut Tjitrosoepomo (1994) jenis-jenis dari famili Zingiberace mengandung minyak atsiri dan resin, serta digunakan sebagai arminatif, stimulans dan pemberi aroma atau bumbu.

Pemanfaatan tanaman dalam famili Zingiberace sebagai obat juga telah banyak ditemukan seperti pemanfaatan Alpinia galanga (Lengkuas), sebagai obat panu; Curcuma domestica (Kunyit), sebagai obat untuk melancarkan darah sehabis melahirkan; Kaempferia galanga (Kencur), sebagai obat terkilir; Zingiber 
officinale (Jahe), sebagai obat sakit perut; dan Zingiber pururem (Bangle), sebagai obat sakit perut atau masuk angin. Ditinjau dari manfaat tanaman obat berdasarkan kajian literatur yang ada, terdapat persamaan dan perbedaan dalam pemanfaatan tanaman sebagai obat oleh masyarakat Desa Pondok Panjang Kabupaten Mukomuko dengan hasil penelitian yang lain. Persamaan dalam pemanfaatan tanaman obat contohnya pemanfaatan Psidium guajava (Jambu biji) oleh masyarakat Desa Pondok Panjang sebagai obat diare, DBD/malaria. Hasil yang sama dilaporkan Sitorus, dkk (2019), bahwa Psidium guajava (Jambu biji) mengobati diare, dan DBD/malaria.

Perbedaan penggunaan tanaman obat contohnya adalah Kaemferia galanga (kencur), yang dimanfaatkan Desa Pondok Panjang sebagai obat terkilir, sedangkan menurut Sitorus, dkk (2019), kencur sebagai obat penambah nafsu makan. Persamaan dan perbedaan pemanfataan tumbuhan sebagai obat dikarenakan adanya perkembangan tentang kajian pemanfataan tumbuhan yang akan dijadikan obat, banyaknya sumber bacaan dan sumber informasi lisan yang berkembang tentang pemanfataan tumbuhan sebagai obat (Windayani,2017).

Tanaman obat di Desa Pondok Panjang Kabupaten Mukomuko digunakan sebagai bahan obat meliputi seluruh bagian tanaman atau bagian- bagian tertentu. Bagian organ tanaman yang digunakan sebagai bahan obat paling banyak yaitu pada bagian daun sebanyak $24(47,05 \%)$ dan yang paling sedikit yaitu umbi sebanyak 1 (1,96\%). Bagian organ tanaman yang digunakan sebagai bahan obat paling banyak menurut penelitian Suhidi, dkk (2017) juga pada bagian daun, yaitu sebanyak Sebanyak 40 jenis tanaman $(43,8 \%)$ dan yang paling sedikit adalah umbi dan getah yaitu hanya terdapat 1 jenis tanaman (1,1\%). Hal ini relevan dengan pernyataan Hamzari (2008) yaitu bagian tumbuhan yang paling banyak digunakan adalah daun karena merupakan tempat pengolahan makanan yang berfungsi sebagai obat, mudah diperoleh dan mudah dibuat atau diramu sebagai obat dibandingkan dengan kulit, batang dan akar tanaman.

Pengembangan LKPD dari hasil penelitian tanaman obat di Desa Pondok Panjang Kabupaten Mukomuko ini dapat digunakan sebagai bahan ajar mata pelajaran biologi kelas $X$ karena telah melewati validasi dari ahli. LKPD hasil pengembangan ini dinyatakan layak oleh validator, karena mendapatkan rata-rata persentase $89 \%$, hal ini sesuai dengan pendapat (Riduwan, 2015) yaitu nilai standar kelayakan ditentukan dengan nilai persentase mencapai $\geq 61$ dengan kriteria valid. Hal ini menunjukkan bahwa LKPD yang telah dikembangkan sudah memenuhi kriteria dan layak untuk digunakan sebagai bahan ajar dalam proses pembelajaran.

Uji keterbacaan atau uji respon dilakukan kepada peserta didik kelas $X$ SMA Negeri 05 Mukomuko. Hasil respon peserta didik terhadap LKPD juga masuk ke dalam kategori "Sangat Baik" dimana rata-rata persentase skor yakni $90 \%$. Hal ini sesuai dengan tabel kriteria persentase keidealan uji respon jika diperoleh skor $>80 \%$ maka masuk dalam kategori "Sangat Baik". Berdasarkan hasil tersebut, LKPD yang telah dikembangan diharapkan mampu memberdayakan pengetahuan siswa tentang pengetahuan tumbuhan obat yang terdapat di Desa Pondok Panjang, Muko-muko.

Desain LKPD hasil pengembangan yang telah divalidasi meliputi; 1) Cover, 2) Judul, 3) Tujuan pembelajaran, 4) Konsep, 5) Alat dan bahan, 6) Cara kerja, 7)Tabel pengamatan, 8) Pertanyaan, dan 9) Kesimpulan. Cover LKPD didesain semenarik mungkin dengan menampilkan 
beberapa foto tanaman obat di Desa Pondok Panjang. Selanjutnya disajikan materi/konsep keanekaragaman dengan memperkenalkan terlebih dahulu tentang Desa Pondok Panjang dan spesies-spesies tanaman obat yang dimanfaatkan oleh masyarakat Desa Pondok Panjang.

\section{PENUTUP}

\section{Simpulan}

1. Jenis-jenis tanaman obat yang dimanfaatkan oleh masyarakat desa Pondok Panjang Kabupaten Mukomuko adalah 45 jenis tanaman obat yang tergolong dalam 28 famili. Famili yang paling banyak ditemukan adalah Zingiberaceae.

2. Organ tanaman obat yang dimanfaatkan oleh masyarakat di desa Pondok Panjang Kabupaten Mukomuko yaitu akar, umbi, rimpang, batang, daun, bunga, buah, biji, yang paling banyak dimanfaatkan adalah daun dengan 24 jenis (47\%) tanaman obat. Cara pengolahan dan penggunaan tanaman obat oleh masyarakat desa Pondok Panjang Kabupaten Mukomuko yang paling banyak digunakan yaitu dengan cara direbus lalu diminum airnya.

3. Tingkat kelayakan LKPD berdasarkan validasi oleh validator memperoleh hasil dengan persentase $89 \%$ dengan kategori sangat valid dan uji respon oleh peserta didik menunjukkan persentase keseluruhan $90 \%$ yang berarti LKPD dinilai sangat baik.

\section{Saran}

LKPD yang telah dikembangkan berdasarkan keragaman tanaman obat dapat digunakan untuk penelitian selanjutnya yaitu pada uji coba skala hasil pada proses pembelajaran untuk melihat keefektifan LKPD.

\section{DAFTAR PUSTAKA}

Hamzari. 2008. Identifikasi Tanaman ObatObatan yang Dimanfaatkan Oleh Masyarakat Sekitar Hutan TaboTabo. Jurnal Hutan dan Masyarakat.

Jumiarni, Wa Ode. 2017. Eksplorasi jenis tanaman dan pemanfaatan tumbuhan obat pada masyarakat suku Muna di Pemukiman Kota Wuna. Jurnal Obat Tradisional, 22(1) 45-56.

Kasrina, Irawati, Sri dan Desmaniar. 2015. Ethnobotanical Study of Medicinal Plants by People of Mukomuko Ethnic in Bengkulu. Jurnal International Seminar on Promoting Local Resources foro Food and Health 127-132.

Leonardo dan Fathul. 2013. Kajian Etnobotani Tumbuhan Obat Di Desa Sekabuk Kecamatan Sadaniang Kabupaten Pontianak (ethnobotany study of medicinal plans in sekabuk village sadaniang district pontianak regency). Pontianak: Universitas Tajnungpura.

Lestaridewi, $\mathrm{Ni}$ Ketut, Jamhari, Muhammad dan Isnainar. 2017. Kajian Pemanfaatan Tanaman Sebagai Obat Tradisional di Desa Tolai Kecamatan Torue Kabupaten Parigi Moutong. Jurnal Inovasi Pendidikan Biologi, 5(2).

Majid, Abdul. 2009. Perencanaan Pembelajaran Mengembangkan Standar Kompetensi Guru. Bandung: PT Remaja Rosdakarya.

Prastowo, Andi. 2011. Panduan Kreatif Membuat Bahan Ajar Inovatif. Yogyakarta: Diva Press.

Riduwan. 2015. Skala Pengukuran Variabel-variabel

Penelitian.Bandung: Alfabeta. 
Sada, J. \&Tanjung, R. H. R. 2010. Keragaman Tumbuhan Obat di Kampung Nansfori Distrik Supiori Utara, Kabupaten Supiori-Papua. Jurnal Biologi Papua. 2(2): 39-46

Sari, Nanda Julia. 2016. Pengembangan Lembar Kerja Siswa Biologi SMA Kelas $X$ Berdasarkan Hasil Penelitian Pemanfaatan Tumbuhan Obat Di Dusun Baru Pelokan Kabupaten Mukomuko. [Skripsi]: Universitas Bengkulu.

Sitorus, B.O.A, Kasrina, \& Ansori, Irwandi. 2019. Pengembangan LKPD Berdasarkan Eksplorasi Tanaman Obat di Suku Pekal. Jurnal Pendidikan dan Pembelajaran Biologi, 3(2): 185-194.

Sugiyono. 2008. Metode Penelitian Pendidikan (Pendekatan Kuantitatif, Kualitatif, dan $R \& D)$. Bandung: Alfabeta.

Suhidi, Kasrina, \& Irawati. 2017. Pengembangan LKS Biologi pada
Siswa Kelas X SMAN 1 Bengkulu Berdasarkan Hasil Studi Pemanfaatan Tanaman Obat di RT. 08 Sukamerindu Kota Bengkulu. Jurnal Pendidikan dan Pembelajaran Biologi, 1 (1): 10-15.

Tjitrosoepomo, G. 1994. Taksonomi Tumbuhan Obat-Obatan Cet. 1. Gadjah Mada University Press. Yogyakarta.

Wasito, Hendri. 2011. Obat Tradisional Kekayaan Indonesia. Yogyakarta: Graha Ilmu.

Windayani. 2017. Pengembangan Buku Saku Biologi Materi Plantae Kelas $X$ SMABerdasarkan Hasil Studi Etnobotani Tanaman Obat Suku Rejang di Kecamatan Merigi Kabupaten Kapahiang. Skripsi Tidak Diterbitkan. Universitas Bengkulu. Program Studi Pendidikan Biologi. 